\title{
複数人による知識創造活動を行う会議に及ぼす室内音環境の影響 INFLUENCE OF SOUND ENVIRONMENT IN MEETING ROOMS ON KNOWLEDGE CREATIVE ACTIVITY IN A GROUP
}

\author{
辻村壮平 ${ }^{* 1}$, 秋田 剛*2, 小島隆矢 ${ }^{* 3}$, 佐野 奈緒子*4 \\ Sohei TSUJIMURA, Takeshi AKITA, Takaya KOJIMA \\ and Naoko SANO
}

\begin{abstract}
In order to investigate an influence of indoor sound environment in office on knowledge creative activity, subjective experiments were conducted in our study. In this experiments, subjective evaluations on "ease of meeting", "quietness of sound environment" and "listening difficulty of speech" in two different types of group meetings (decision-making meeting and discussion to think of creative ideas) were measured under five types of sound environmental conditions (no-noise $L_{\mathrm{Aeq}, 5 \min } 38 \mathrm{~dB}$, ambient noise (conversation noise) $L_{\mathrm{Aeq}, 5 \min } 40 \mathrm{~dB}, 45 \mathrm{~dB}, 50 \mathrm{~dB}, 60 \mathrm{~dB}$ ) in a meeting room of the university. From the results, in regard to "quietness of sound environment", we found that subjects start feeling noisy (not quiet) in sound environmental condition of ambient noise $50 \mathrm{~dB}$, and that of $60 \mathrm{~dB}$ have an increased "listening difficulty of speech". In the ambient noise $50 \mathrm{~dB}$, "ease of meeting" was the highest evaluation for discussion to think of creative ideas among these experimental conditions. Furthermore, to investigate psychological factors related to ease of meeting, multiple regression analysis was performed using the data obtained from subjective experiments. These results of multiple regression analysis show that a quiet sound environment is not necessarily desirable in discussion to think of creative ideas. It was found that very quiet sound environment decrease the evaluation of "ease of meeting" in discussion to think of creative ideas. Thus, it was suggested that recommended indoor sound environmental condition to conduct discussion to think of creative ideas was ambient noise $50 \mathrm{~dB}$.
\end{abstract}

Keywords: Meeting room environment, Knowledge creative activity, Ease of meeting, A-weighted sound pressure level, Ambient noise 会議環境，知識創造活動，会議のしや寸さ，騷音レベル，会話雑音

\section{1. はじめに}

近年、知識創造の価值の割合が高い商品やサービスを提供する産 業の生産額は日本の経済全体の大部分を占めている ${ }^{1)}$ ここような 知識社会の出現に伴い、室内環境の質の向上を図る取り組みの一つ として執務空間の知的生産性に着目した研究が活性化しており、知 的生産性や感性価值創造活動の向上に資するオフィス環境の整備が 望まれている2)。感性や創造性を高め、知識創造を誘発するような オフィス環境を充実させるには企業の組織知を強化することが不可 欠であり、そのためには会議室や共有スペースなど知識創造活動を 実施する空間においてコミュニケーションの活性化が求められる。 コミュニケーションの活性化については物理的に会話が増えること が重要ではなく、良好な人間関係を築けるような䨌囲気を有する環 境デザインを目標としなければならない ${ }^{3)}$

室内音環境と知的生産性に関連する既往研究として、例えば、一 人で実施する単純計算作業や暗記学習、作文課題などに対する音環

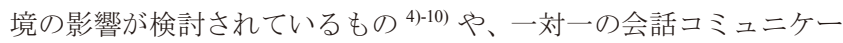

ションに及ぼす音環境の影響を調べた研究 ${ }^{11)}$ が報告されている。こ れらのうち殆どは個人で実施する作業に着目し、音環境と作業効率 の関係について検討が行われている。作文課題を採用し、拡散的思 考と収束的思考に及ぼす音環境の影響を検討している佐久間らの研 究9) では、 4 人 1 組を同室に着席させて課題を行わせているものの、 課題は個人が各々独立して実施するものであり、対人意識が伴う執 務空間における知的生産性と音環境の関係性に着目している。

このように、室内音環境と知的生産性に関しては個人で取り組む 課題の知的活動階層の違いや、二人で行う会話などと音環境の関係 については研究が進められており、これまでに多大な研究成果が蓄 積されている。一方で、実際のオフィスで実施される知識創造活動 としては複数人で形成されたグループで集まって会議が行われる場 面が多い。従って、集団で行う知識創造活動に対する音環境の影響 を検討することも重要となる。複数人での知識創造活動に着目した 既往研究として、前田ら ${ }^{12)}$ はテーブルの有無や椅子の形状、植栽の 有無など、空間の構成要素に着目し、室内の空間レイアウトが知識
*1 (公財) 鉄道総合技術研究所 副主任研究員 - 博士 (工学)

*2 東京電機大学未来科学部建築学科 教授·博士 (工学)

*3 早稲田大学人間科学学術院 准教授. 博士 (工学)

*4 東京電機大学未来科学部建築学科 非常勤講師・博士 (工学)
Assist. Senior Researcher, Architecture Laboratory, Railway Technical Research Inst. , Dr. Eng.

Prof., Dept. of Arch., Sch. of Sci. and Tech. for Future Life, Tokyo Denki Univ., Dr.Eng. Assoc. Prof., Faculty of Human Sciences, WASEDA University, Dr.Eng.

Part-time Lect., Dept. of Arch., Sch. of Sci. and Tech. for Future Life, Tokyo Denki Univ., Dr.Eng. 
創造活動に及ぼす影響を検討しているが、この研究では音環境には ふれられていない。

そこで本研究では、複数人で知識創造活動を行う状況における室 内音環境と知的生産性の関係に着目し、その端緒として、環境音の 騒音レベルと「会議のしやすさ」の関係を調べることを目的に、主 観評価実験を実施した。また、「会議のしやすさ」という心理的印象 と関連のある心理的要因を明らかにするために、主観評価実験によ って得られた心理量データを用いて重回帰分析による因果モデルの 検討を行った。

\section{2. 複数人での知識創造活動に関する主観評価実験}

\section{1 実験条件}

実際のオフィスで行われる会議の内容を大きく分類すると、意見 を集約して業務の方向性・計画性を決めるような意思決定プロセス や、新たな製品やアイディアを検討・提案するような知識創造プロ セスが実施されている。また、IT 技術や電子通信技術の発展に伴い、 現代のオフィスでは多様なワークスタイルの選択が可能となってお り、テレビ会議など遠隔地の人と会議を行う機会も増加している ${ }^{13)}$ しかし実際には、通信会議では意思決定プロセスが行われることが 多く、知識創造プロセスを必要とする場合、通信会議より対面会議 が行われることが多い。

そこで本研究では、対面会議で意思決定プロセスを行う会議（以 下、意思決定活動と記す) と知識創造プロセスを要する会議 (以下、 知識創造活動と記す）の 2 種類の会議内容について、会議のしやす さの印象と音環境の関係を検討した。意思決定活動では既存の知識 を用いた情報の整理・共有、意見の集約、業務計画の立案などを行 い、知識創造活動では新しい製品やアイディアの提案を目的とした 不特定の情報から未知なる成果を創造するような課題内容を設定し た。それぞれの会議で被験者が取り組んだテーマを Table1 に示す。 本実験に用いた環境音は、オフィス内で想定される騒音の一つと して、会話の内容は理解できない複数の音声雑音（以降、会話雑音 と記す）に着目し、東京電機大学東京千住キャンパス 1 号館で開催 された日本感性工学会のポスターセッションの会場において各発話 者から周囲 $5 \mathrm{~m}$ 以上離れた位置で会話雑音の録音を行った。高さ 1.2 $\mathrm{m}$ に設置した騒音計（小野測器, LA-2111）からリニア PCM レコー ダー（SONY, PCM-D50）に会場の会話雑音を 15 分間録音し、この うちの 5 分間の音源データを本実験で環境音として用いた。

本実験では、各被験者の座席で会話雑音の提示レベルが等しくな るように、被験者グループが作業する机の両脇にスピーカを左右対 称に 1 台ずつ設置し注 1)、Fig.1 に示した測定点において $L_{\text {Aeq, } 5 \text { min }}$ でそ れぞれ 40, 45, 50, $60 \mathrm{~dB}$ に設定した。本実験で会話雑音をスピーカか ら再生したときの測定点での周波数特性を Fig.2 に示す。これらの 4 水準に「騒音なし (暗騒音)」の条件 $\left(L_{\mathrm{Aeq}, 5 \mathrm{~min}} 38 \mathrm{~dB}\right.$ ) を加えた計 5 水準を音環境条件とした。本実験で設定した音環境条件をTable2 に 整理する。

\section{2 実験手順}

本研究では、オフィスにおいてプロジェクトチーム単位で会議を 行う状況を想定しているため、相手との親密度に関する事前アンケ 一ト調查を実施し、親密度の高い被験者を 4 名 1 組として 10 組の被 験者グループを作った。これらのグループに対して、会議内容とし
Table1 Specific contents of each meeting

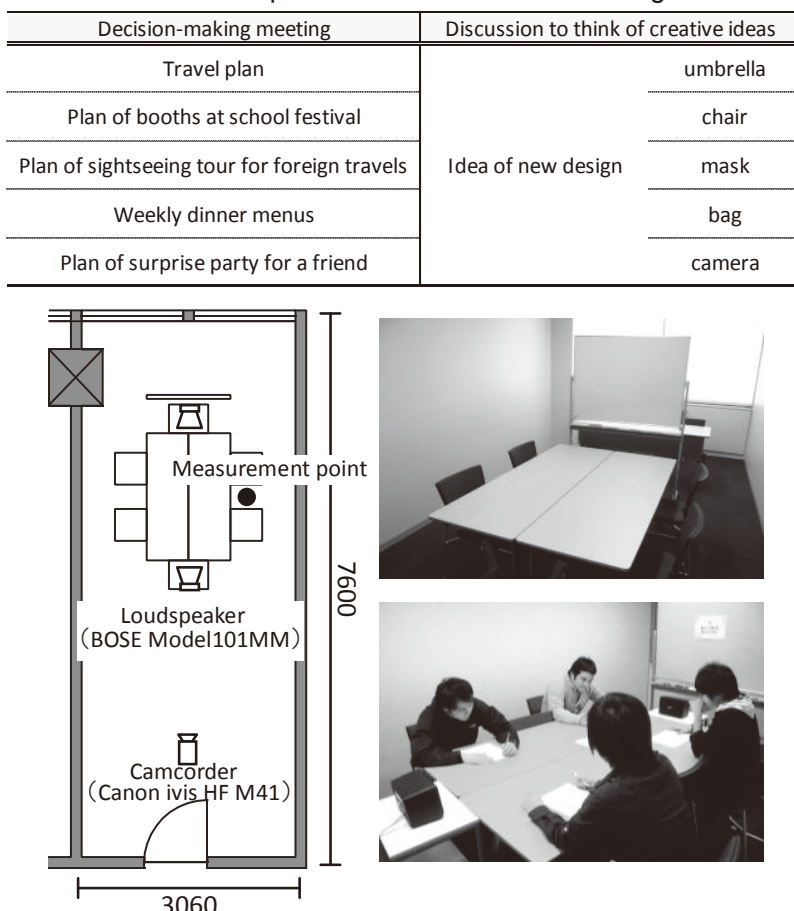

Fig.1 State of subjective experiment

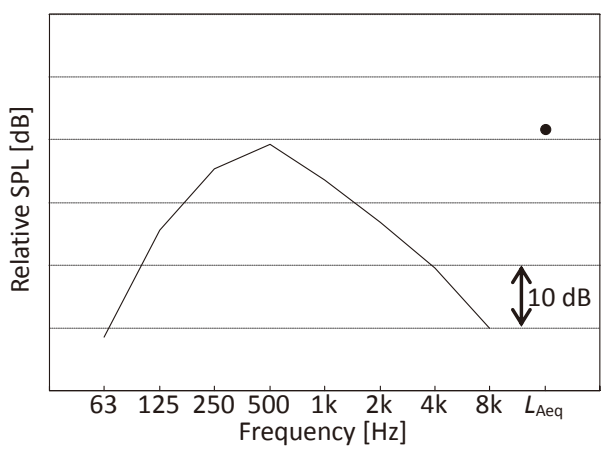

Fig.2 Frequency characteristics of conversation noise used in this experiment

Table2 Sound environmental conditions

\begin{tabular}{c|c}
\hline Kind of environmental noise & $L_{\text {Aeq, } 5 \mathrm{~min}}$ \\
\hline \hline No-noise (Background noise) & $38 \mathrm{~dB}$ \\
\hline \multirow{3}{*}{ Conversation noise } & $40 \mathrm{~dB}$ \\
\cline { 2 - 2 } & $45 \mathrm{~dB}$ \\
\cline { 2 - 2 } & $50 \mathrm{~dB}$ \\
\cline { 2 - 2 } & $60 \mathrm{~dB}$ \\
\hline
\end{tabular}

て意思決定活動と知識創造活動を 5 組 20 名にそれぞれに割り当て、 会議内容ごとに Table1 の 5 テーマを設定した。本実験の被験者は 18 〜24 歳の聴力正常な男性 40 名である。

被験者グループには、前述の Fig.1 で示した東京電機大学東京千 住キャンパス 1 号館の会議室で、意思決定活動あるいは知識創造活 動のいずれかの会議内容の5テーマに関する会議をそれぞれ 20 分間 実施させた。被験者の疲労を考慮し、各テーマの会議終了後には 5 分間の休㮩を設けた。すなわち、本実験は被験者グループ 1 組につ き、 20 分間 $\times 5$ テーマの会議に各会議終了後の休慜 5 分間 $\times 4$ 回の 計 120 分間というスケジュールである。

会議に関しては、意思決定活動及び知識創造活動のいずれの会議 内容でも、各テーマに対する結論を必ずまとめるよう被験者に教示 
Table3 32 evaluation items used in this experiment

\begin{tabular}{|c|c|c|c|c|c|}
\hline \multicolumn{3}{|c|}{ Evaluation item for situation of meeting } & \multicolumn{3}{|c|}{ Evaluation item for outcome of meeting } \\
\hline 会議しにくい & - & 会議しやすい & 不満な & - & "満足な \\
\hline 会話しにくい & - & 会話しやすい & 達成感がない & - & 達成感がある \\
\hline 発話しにくい & - & 発話しやすい & つまらない & - & 興味深い \\
\hline （相手に）声を伝えにくい & - & （相手に）声を伝えやすい & 魅力的でない & - & 魅力的である \\
\hline 音声を聴き取りにくい & - & 音声を聴き取りやすい & 意見を言えない & - & 意見を言える \\
\hline つまらない & - & 楽しい & 意見がまとまらない & - & 意見がまとまる \\
\hline 会話が弾まない & - & 会話が弾む & 取り組めない & - & 取り組める \\
\hline 緊張する & - & リラックスする & 良い話し合いができない & - & 良い話し合いができる \\
\hline \multirow[t]{2}{*}{ 疲れる } & - & 疲れない & 難しい & - & 易しい \\
\hline & & & 関心がない & - & 関心がある \\
\hline \multicolumn{3}{|c|}{ Evaluation item for sound environment } & \multicolumn{3}{|c|}{ Evaluation item for meeting space } \\
\hline 不快な & - & 快適な & 不快な & - & 快適な \\
\hline うるさい & - & 静かな & 居心地が悪い & - & 居心地がよい \\
\hline 親しみにくい & - & 親しみやすい & リラックスできない & - & リラックスできる \\
\hline 活気のない & - & 活気のある & 暗い & - & 明るい \\
\hline 騒がしい & - & 落ち着く & 閉鎖的な & - & 開放的な \\
\hline \multirow[t]{2}{*}{ 気になる } & - & 気にならない & 狭い & - & 広い \\
\hline & & & 他者との距離が近い & - & 他者との距離が遠い \\
\hline
\end{tabular}

を与えている。会議内容ごとの 5 テーマと音環境条件の 5 水準を各 被験者グループで偏りなく組み合わせるためにラテン方格によって 条件の割り付けを行い、さらに各テーマと音環境条件の順序効果に 配慮し、被験者グループごとに提示順序はランダムとした。実験中 の音環境以外の環境条件を把握するために会議室の温度、湿度、机 上面照度を測定し、実験中の環境条件は室温 19 20 ${ }^{\circ} \mathrm{C} 、$ 湿度 $30 \%$ 、 机上面照度 700 750 lx であったことを確認した。

各実験条件での会議の終了後、会議の内容・状況に関する 9 項目、 会議の成果に関する 10 項目、音環境に関する 6 項目、空間の印象に 関する 7 項目の合計 32 の評価項目について、それぞれ 5 段階の評定 尺度で被験者に評価を求めた。本実験で用いた評価項目及び 5 段階 評定尺度を Table3、Fig.3にそれぞれ示す。

既往研究によれば、会議の話題は「進め方の議論 (コンテクスト)」 と「中身の議論（コンテント）」に分類され、両者の遷移回数や、会 議中に会話が止まり、会議が停滞している時間などによって会議の

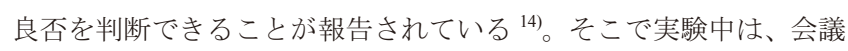
の様子をビデオカメラで撮影し、会議中に全員の会話が止まり、会 議が停滞している時間（以降、沈然時間と記す）や話題の遷移回数 (議論の内容が移り変わる回数) を計測した。さらに実験終了後に は被験者に対し、簡単なヒアリング調査を行った。

\section{3 実験結果及び考察}

(1) 音環境に対寸る主観評価と騒音レベルの関係

各評価項目と音環境の影響の関連性を検討するため、本実験で用 いた 32 項目について、音環境条件と会議内容を要因とした二元配置 分散分析を行った結果を Table4 に示す。「会議しや寸さ」、「会話し やすさ」、「声の伝えやすさ」、「音声の聴き取りやすさ」、「会話の弾 み」、などの他者とのコミュニケーションに関わる印象や、「快適性 (音)」、「静かさ」、活気」、「落ち着き」、「気になる程度」という会 議時の音環境に対する印象、「満足感」、「達成感」「「魅力」、「意見の まとまり」、「良い話し合い」、「難易度」などの会議を行った結果の 内容に関する印象で音環境の主効果が有意に認められており、音環 境の違いによってこれらの評価に差異が表れやすいことがうかがえ る。また、会議室の空間的印象に関する評価項目では、「リラックス

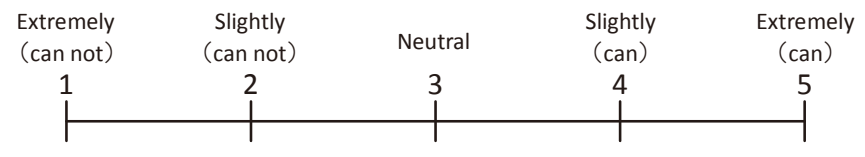

Fig.3 5-step category scale

\begin{tabular}{|c|c|c|c|}
\hline & Table4 Result of Two- & ANOVA & $\begin{array}{l}*: p<0.01 \\
*: p<0.05\end{array}$ \\
\hline & 32 Evaluation items & $\begin{array}{l}\text { Main effect } \\
\text { of sound } \\
\text { environment }\end{array}$ & $\begin{array}{c}\text { Main effect } \\
\text { of types } \\
\text { of meeting }\end{array}$ \\
\hline \multirow{9}{*}{$\begin{array}{c}\text { For situation } \\
\text { of meeting }\end{array}$} & 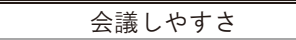 & * & n.s. \\
\hline & 会話しやすさ & * & n.s. \\
\hline & 発話しやすさ & n.s. & $* *$ \\
\hline & 声の伝えやすさ & $*$ & n.s. \\
\hline & 音声の聴き取りやすさ & $* *$ & n.s. \\
\hline & 楽しさ & n.s. & n.s. \\
\hline & 会話の弾み & $* *$ & n.s. \\
\hline & リラックス (会議) & n.s. & $* *$ \\
\hline & 疲労感 & n.s. & n.s. \\
\hline \multirow{6}{*}{$\begin{array}{l}\text { For sound } \\
\text { environment }\end{array}$} & 快適性（音） & $* *$ & n.s. \\
\hline & 静かさ & $* *$ & n.s. \\
\hline & 親しみ & n.s. & n.s. \\
\hline & 活気 & $* *$ & n.s. \\
\hline & 落ち着き & $* *$ & n.s. \\
\hline & 気になる程度 & $* *$ & * \\
\hline \multirow{10}{*}{$\begin{array}{l}\text { For outcome } \\
\text { of meeting }\end{array}$} & 満足度 & $* *$ & n.s. \\
\hline & 達成感 & $* *$ & n.s. \\
\hline & 興味 & n.s. & $* *$ \\
\hline & 魅力 & $* *$ & n.s. \\
\hline & 意見の言いやすさ & n.s. & n.s. \\
\hline & 意見のまとまり & $* *$ & n.s. \\
\hline & 取り組み & n.s. & n.s. \\
\hline & 良い話し合い & $* *$ & n.s. \\
\hline & 難易度 & $*$ & n.s. \\
\hline & 関心 & n.s. & n.s. \\
\hline \multirow{7}{*}{$\begin{array}{l}\text { For meeting } \\
\text { space }\end{array}$} & 快適性（空間） & n.s. & n.s. \\
\hline & 居心地 & n.s. & n.s. \\
\hline & リラックス（空間） & $*$ & $*$ \\
\hline & 明るさ & n.s. & $* *$ \\
\hline & 開放感 & n.s. & n.s. \\
\hline & 広さ & n.s. & $*$ \\
\hline & 他者との距離 & n.s. & n.s. \\
\hline
\end{tabular}


(空間)」のみ音環境の主効果が有意に示されており、リラックスす る䨌囲気を作り出すには音環境が重要となることが示唆される。

音環境の印象と騒音レベルの関係を検討するため、「音環境の静か さ」と「音声の聴き取りやすさ」の評価項目に着目し、これらの評 価項目と音環境条件の関係を整理した。分析に用いた評価得点デー タのサンプル数は被験者 40 名 $\times$ 音環境条件 5 水準の $\mathrm{N}=200$ である。 「音環境の静かさ」及び「音声の聴き取りやすさ」と音環境条件の 関係を Fig.4 及び Fig.5 にそれぞれ示す。

「音環境の静かさ」に関して、音環境条件と会議内容を要因とし た二元配置分散分析を行った結果、音環境条件の主効果のみ有意に 認められた $(p<0.01)$ 。Fig.4 に多重比較の結果を示すが、いずれの 会議内容でも室内の騒音レベルが高くなると「静かさ」の評価が低 くなる傾向が認められる。この結果をみると、 $50 \mathrm{~dB}$ を超えるとう るさいと感じ出し、60 dB ではうるさい印象となっていることがう かがえる。一方、「音声の聴き取りやすさ」に関しては、会議内容ご とに音環境条件を要因とした一元配置分散分析を行った結果、いず れの会議内容においても音環境の主効果が有意に認められた $(p<0.01)$ 。Fig.5 に多重比較の結果を示寸が、 $60 \mathrm{~dB}$ と暗騒音、 $40 \mathrm{~dB}$ の各条件で両会議内容ともに有意な差異が認められ $(p<0.01) 、 60 \mathrm{~dB}$ と $45 \mathrm{~dB}$ については知識創造活動のみで有意差が認められた。この 結果から、いずれの会議内容でも $60 \mathrm{~dB}$ では音声の聴き取りやすさ の評価は低下していることがわかる。

公共空間の音環境を評価した横山らの研究 ${ }^{15)}$ では、騒音レベルが 約 $63 \mathrm{~dB}$ で喧騒感を感じるようになり、会話に対しては騒音レベル が $62 \mathrm{~dB}$ 程度で少し邪魔になる印象が生じることが報告されている。 また、初対面時の室内音環境と会話コミュニケーションの関係を調 ベた三上らの研究 ${ }^{11)}$ では、BGM と空調音を同時に提示した条件で 騒音レベルが $55.4 \mathrm{~dB}$ の場合、若干うるささを感じるが、相手の音 声は聴き取りにくくはならず、 $64.1 \mathrm{~dB}$ で相手の音声が少し聴き取り にくくなることが報告されている。

これらの既往研究の知見と本研究の Fig.4 及び Fig.5 の結果から、 音環境の静かさと会話のしやすさという観点では、室内の騒音レベ ルは $60 \mathrm{~dB}$ ではうるさい印象となり、会話に対しても妨害的に作用 しやすいことが示唆される。

\section{（2）「会議のしやすさ」の印象之音環境の関係}

「会議のしやすさ」に及ぼす音環境の影響を調べるため、「会議の しやすさ」と音環境条件の関係を Fig.6 に整理した。「会議のしやす さ」に関して、意思決定活動と知識創造活動のそれぞれの会議内容 について、音環境を要因とした一元配置分散分析を行った。その結 果、知識創造活動でのみ音環境の主効果が有意に認められた $(p<0.01)$ 。さらに多重比較によれば、 $50 \mathrm{~dB}$ と暗騒音、 $40 \mathrm{~dB} 、 60 \mathrm{~dB}$ の各条件間でそれぞれ有意な差異が示され、知識創造活動の「会議 のしやすさ」の評価值は $50 \mathrm{~dB}$ で最も高い。意思決定活動では $40 \mathrm{~dB}$ から $60 \mathrm{~dB}$ の範囲においては音環境が「会議のしやすさ」に及ぼす 影響は小さく、いずれの条件でも比較的会議は行いやすいと評価さ れるが、知識創造活動では音環境の影響が表れやすく、50 dB 程度 の会話雑音が存在する音環境が会議を行いやすいと評価されている。 実験後のヒアリング調査で、意思決定活動に取り組んだ被験者か らは「人の会話がよく聴こえて会議を進めや寸い、「周囲の音が大 きくなると相手の声が少し聴き取りにくくなった」などの意見がみ

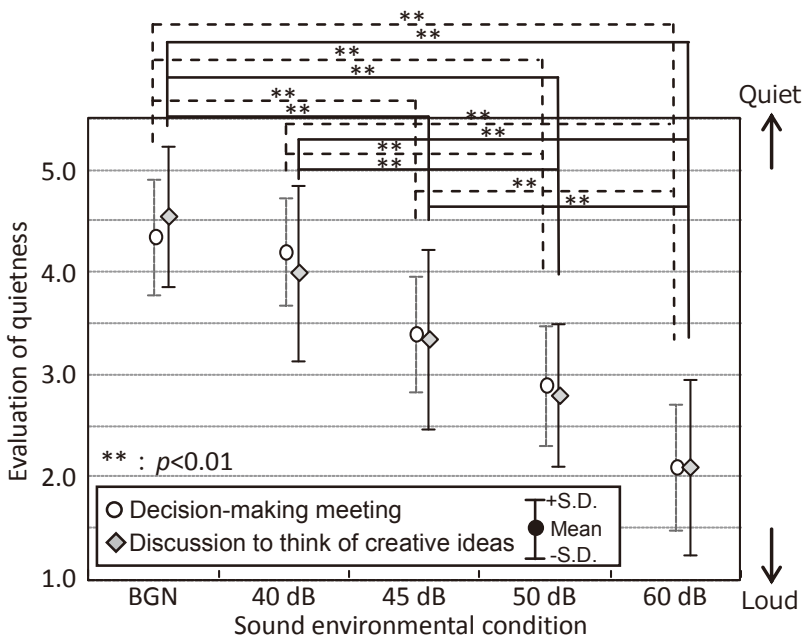

Fig.4 "Evaluation of quietness" for each noise level

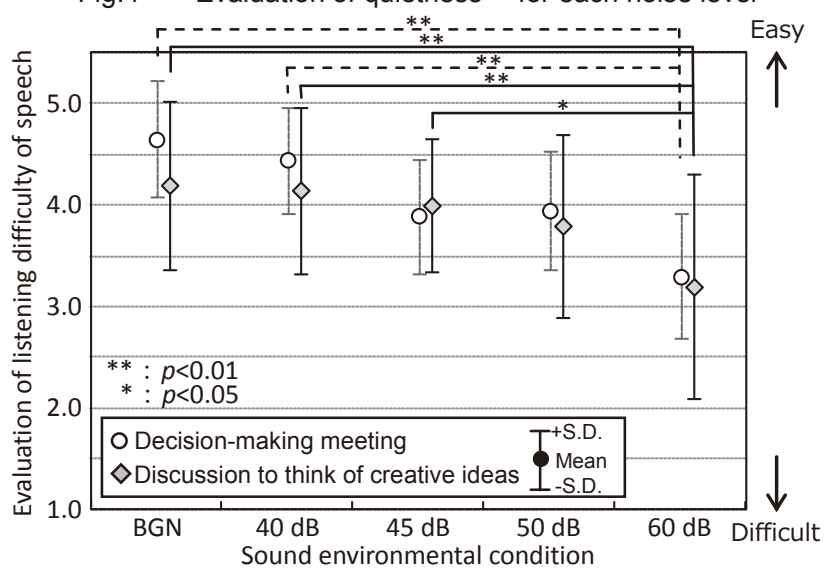

Fig.5 "Evaluation of listening difficulty of speech" for each noise level

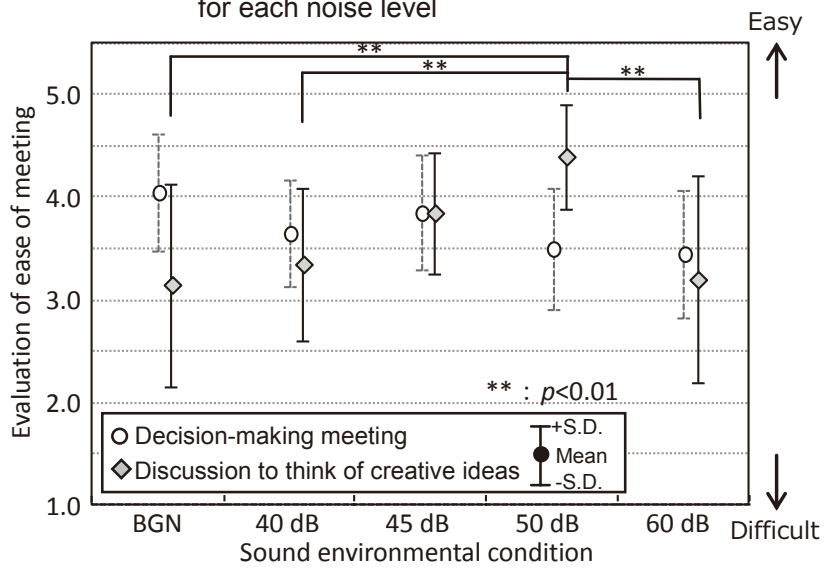

Fig.6 "Evaluation of ease of meeting" for each noise level

られ、知識創造活動に取り組んだ被験者からは「静かすぎると会話の 間がもたないりや沈黙しているときに周囲が静かな状態だとその時 間が辛い」などの意見がみられた。これらより、意思決定活動では 「グループ内の相手の意見を正確に聴き取ること」が重視され、知 識創造活動では「グループ内の相手の意見に対して自身の考えを発 言し、意見を交換すること」が重視されている可能性がある。

「聴き取りやすさ」と音環境条件の関係を示した前述の Fig.5 の 結果をみると、意思決定活動の「聴き取りやすさ」の評価の平均值 はいずれの音環境条件でも 5 段階評価の「3.どちらともいえない」 より聴き取りやすいという判断になっている。また、Fig.6 の結果で も、意思決定活動では「会議のしやすさ」の評価の平均值はいずれ 
の音環境条件でも 5 段階評価の「3.どちらともいえない」より会議 しやすいという判断になっている。

以上より、本研究で設定した $40 \mathrm{~dB}$ から $60 \mathrm{~dB}$ の範囲では、意思 決定活動において相手の音声が聴き取りにくいという印象をもつ音 環境ではなかったと考えられ、意思決定活動では「会議のしやすさ」 への音環境の影響は有意に表れなかったと示唆される。

\section{（3）会議内容による行動観察データの差異}

沈黙時間と音環境の関係を Fig.7 に示す。音環境と会議内容を要 因とした二元配置分散分析を行った結果、音環境の主効果は認めら れず、会議内容のみ主効果が有意であり $(p<0.01)$ 、意思決定活動よ りも知識創造活動の方が沈黙時間は長くなっている。標準偏差に着 目すると、意思決定活動に比べて知識創造活動では沈黙時間のばら つきが大きい。既存の知識を用いて情報を整理・共有する意思決定 活動に比べて、知識創造活動では相手との会話によって得られた不 特定多数の情報を発展させ、未知なる成果を創造することが行われ ているため、後者の方が黙考する状況が多くなり、沈黙時間が長く なったと考えられる。

一方、話題の遷移回数に関しても同様に、音環境と会議内容を要 因とした二元配置分散分析を行ったところ、いずれの要因について も主効果は有意に認められなかった。この理由として、既往研究 ${ }^{14)}$ では 2 時間の会議であったのに対し、本研究では 1 テーマで 20 分間 と短かったため、話題の移り変わりの回数に差異が表れるには十分 な時間ではなかった可能性がある。

\section{4 心理的要因に関する分析方針}

前節では音環境条件による心理評価の違いを分散分析により検討 したが、次章以降ではその結果をふまえて「会議のしやすさ」に関 する心理的要因を分析する。分析方法としては、会議の状況や環境 に対寸る心理評価項目を説明変数とした重回帰分析を用いるが、本 報における重回帰分析は因果関係の推論手法として用いるものであ り、予測モデル作成という本来の用法とは分析の指針が異なる部分 がある。

これについて、回帰分析の本来の用途は予測であり、因果関係の 分析に用いることは長く禁忌とされていた ${ }^{16)}$ 。しかし、2000 年頃 より、回帰分析を因果分析に用いるための枠組みが理論的・実践的 に整備されてきており (小島 ${ }^{17)}$ 、宮川 ${ }^{18)}$ など)、その具体的指針は 以下の通りである。

・目的変数から影響を受ける結果側変数を説明変数に含めない。

・目的变数への影響を把握したい変数（要因）と相関があり、目的 変数にも影響する可能性がある変数（共変量）は、有意な効果を もつ変数を選択して説明変数に含める。

・偏回帰係数は単純に「目的変数への効果」を表すのではなく、「モ デルに含む他の説明変数が一定という条件の下での目的変数への 効果」を表すことに注意して、結果の解釈・考察を行う。

・具体的な注意点としては、説明変数間に因果関係がある場合、偏 回帰係数は「他の説明变数を経由した間接的な影響」を除去した 残りの効果を表す（必要に応じてこのような間接効果を加味した 考察や間接効果を把握するための説明変数間の回帰分析を行う)。

・モデルに含む共変量にも「一定」という条件が付く（偏回帰係数 は共変量による疑似相関を除去した因果的影響を表す)。

小島 ${ }^{17)}$ は、「高相関の変数を同時に用いない」という従来の教え

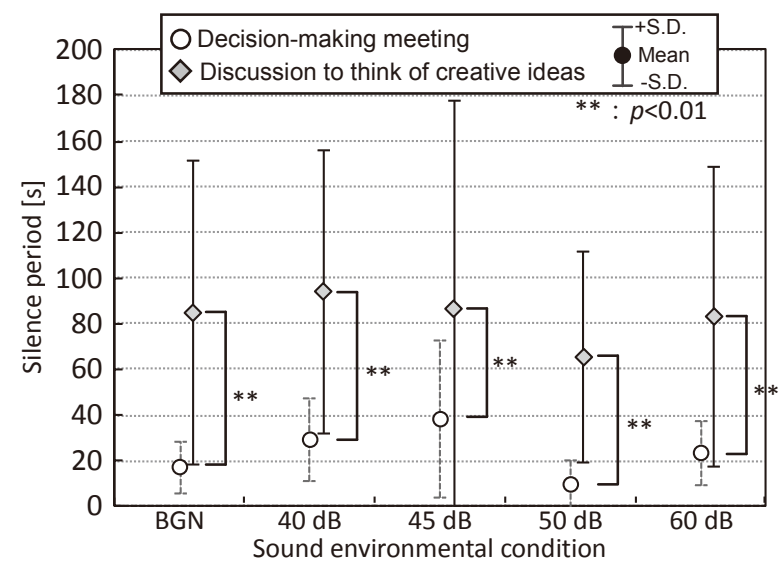

Fig.7 Relationship between silence period and noise level for each meeting

は予測モデル作成のためには効率的であるが、因果分析においてこ の指針に従った場合、関心のある要因との相関が高い重要な共変量 がモデルから外され、その共変量による疑似相関が偏回帰係数に加 算されることになり、危険であることを指摘している。さらに、「高 相関の変数を同時に用いない」という従来の教えが回帰分析の要点 として強調されすぎたため、本来の多重共線性（推定不能な程の共 線性）と、モデルに含む説明変数によって偏回帰係数が変わるとい う妥当な現象（推定不能な程の共線性はない）がどちらも「多重共 線性」として混同されている現状を問題としている。本報では本来 の多重共線性に注意して分析を進めることが必要になるが、その判 断基準としては推定值の検定 ( $p$ 值 $<0.05)$ 、参考として VIF 值を用 いることとする ${ }^{19)}$

また、これまでの分析結果から要因効果が直線的でないことが示 唆されるため、最終的には 2 次の項を取り入れ曲線的な効果を表現 できるモデルを想定するが、探索段階としてまず 1 次の項のみのモ デル化を行い、有意な効果を持つ要因について 2 次の項の追加を検 討するという原則に従って分析を進める。このとき、1 次の項と 2 次の項が高相関となることを防ぐために、評価平均值で中心化した 形の 2 次式で予測式を構成する注2)。

\section{3.「会議のしやすさ」の印象と関連のある心理的要因}

\section{1 主観評価実験データの分析方法}

「会議のしやすさ」に影響を及ぼす心理的要因を調べるため、「会 議のしやすさ」を目的変数に、前述の Table 3 で示した 32 の評価項目 を説明変数の候補として重回帰モデルを検討する。まず予備的検討 として、各会議内容において音環境を要因とした一元配置分散分析 を行った。その結果、意思決定活動では 13 項目、知識創造活動では 12 項目に音環境の主効果が有意に認められたため、これらの評価項 目に着目し、因果順序を考えた際に「会議のしや寸さ」より結果側 の変数となり得る項目を除いた評価項目を説明変数の候補とした。

次に、JMP10.0.2 ソフトウェアを用いて、上述の候補の中から変 数増減法によるステップワイズ式变数選択を実施し、説明変数に採 用する評価項目を抽出した。その結果、「会話のしやすさ」、「聴き取 りやすさ」、「静かさ」の主効果が有意となり $(p<0.05)$ 、これら 3 項 目を説明変数に取り入れた重回帰モデルを検討することとした。会 議内容ごとのこれらの説明変数間の相関係数行列を Table 5 に示寸が、 各説明変数間の VIF 值を算出するといずれも 1.5 未満と小さく ${ }^{19)}$ 、 
多重共線性は回避されることを確認している注3)。

\section{2 「会議のしやすさ」と各評価項目の関係}

意思決定活動および知識創造活動の会議内容ごとに、「会議のしや すさ」を目的変数に、「会話のしやすさ」、「聴き取りやすさ」、「静か さ」を説明変数に用いて重回帰分析を行った。その結果、いずれの 会議内容においても「会話のしやすさ」と「聴き取りやすさ」の主効 果が有意となり $(p<0.05)$ 、「静かさ」に関しては知識創造活動でのみ 主効果が有意に示され $(p<0.05)$ 、交互作用が認められた。そこで、 「静かさ」については会議内容による違いを明示するため、名義尺度 である「会議内容」を説明変数に取り入れ、要因効果が会議内容の 水準ごとに「枝分かれ注 ${ }^{4} 」$ するように表現しなおして重回帰分析を 行った。その結果を Table6 に示す。

Table6 より、この重回帰モデルの自由度調整済み決定係数は 0.569 であり、比較的説明力の高いモデルが得られている。それぞれの説 明変数の偏回帰係数に着目寸ると、「会話のしやすさ」は 0.614、「聴 き取りやすさ」は 0.127 であり、主効果が有意となっている(「会話 のしやすさ」: $p<0.01$ 、「聴き取りやすさ」 $p<0.05)$ 。「静かさ」に関 しては、「静かさ[意思決定]」は $0.014 、 「$ 静かさ[知識創造]」は-0.156 であり、水準[意思決定]の場合は有意な効果はなく、水準[知識創造] の場合には有意な負の効果が示されている $(p<0.01)$ このモデルに よれば、「会話のしやすさ」と「聴き取りやすさ」が同じならば、知 識創造活動の場合は「静かでない」方が「会議しや寸い」と解釈す ることができる。

この結果から、いずれの会議内容でも、「会議のしやすさ」への寄 与は「会話のしやすさ」の影響が最も大きく、「会話のしやすさ」は 「会議のしやすさ」を構成する重要な要因となっていることがわか る。「聴き取りやすさ」もいずれの会議内容でも同程度の正の影響を 持つという点は共通しているが、その影響は「会話のしやすさ」よ りも小さい。「静かさ」の影響は会議内容によって異なり、知識創造 活動でのみ「会議のしやすさ」は「静かさ」から有意な負の影響が みられた $(p<0.01)$ 。このことから、知識創造活動では、必ずしも静 かな環境が望ましいとはいえず、むしろ静かすぎる環境は「会議の しやすさ」を低下させることが示唆される。

ここでは「静かさ」の 2 次の項の追加も検討したが、2 次の項は 有意とならなかった。従って、このモデルにおいて「静かさ」の非 直線的な効果は、効果の大きい「会話のしやすさ」を介した間接的 影響に含まれており、「静かさ」、聴き取りやすさ」、「会話しやすさ」 から「会議しやすさ」への効果を表寸関数形としては 1 次式で十分 であると考えられる。

\section{4. 会議内容ごとの「会話のしやすさ」の評価構造モデルの検討 \\ 4.1 分析方法}

前章では、会議内容によらず「会話のしやすさ」が「会議のしや すさ」に対する寄与が大きいこと、会議内容によって「静かさ」の 影響が異なること（知識創造活動では負の影響）が示された。そこ で本章では、「会話のしやすさ」を目的変数とし、「静かさ」を含め た音環境に関する 6 項目を説明変数の候補として、以下のような手 順で重回帰モデルを検討する。

また、ここで説明変数とする音環境に関する評価は個人別の評価 值が測定されているものの、同一環境・課題で会議を行った 4 人の
Table5 Correlation coefficient matrix

\begin{tabular}{l|c|c|c|c} 
& \multicolumn{4}{|c}{ 知識創造活動 } \\
\cline { 2 - 5 } 意 & Explanatory variable & 会話のしやすさ & 聴き取りやすさ & 静かさ \\
\cline { 2 - 4 } 思 & 会話のしやすさ & & 0.393 & 0.168 \\
\cline { 3 - 5 } 決 & 聴き取りやすさ & 0.525 & & 0.491 \\
定 & 静かさ & 0.253 & 0.560 & \\
活 & 動 & &
\end{tabular}

Table6 Result of multiple regression analysis for "Ease of meeting"

\begin{tabular}{|c|c|c|c|}
\hline $\begin{array}{c}\text { Objective } \\
\text { variable }\end{array}$ & $\begin{array}{l}\text { Adjusted } \\
\text { R-square } \\
\end{array}$ & Explanatory variable & $\begin{array}{c}\text { Partial regression } \\
\text { coefficient }\end{array}$ \\
\hline \multirow{5}{*}{$\begin{array}{l}\text { 会議の } \\
\text { しやすさ }\end{array}$} & \multirow{5}{*}{0.569} & 会話のしやすさ & $0.614 * *$ \\
\hline & & 聴き取りやすさ & $0.127^{*}$ \\
\hline & & 会議内容[意思決定] : 静かさ & 0.014 \\
\hline & & 会議内容[知識創造] : 静かさ & $-0.156 * *$ \\
\hline & & 会議内容 & -0.035 \\
\hline
\end{tabular}

評価の差は小さい場合が多い。すなわち、名目上は $\mathrm{N}=200$ (会議 50 回 $\times 4$ 名）のデータだが、実質的な情報は $\mathrm{N}=50$ （会議回数）に近い という「自由度の水増し」が危惧される。そこで、50回の「会議」 を変量因子 ${ }^{20)}$ として取り入れ、会議間残差と会議内個人差という2 つの残差成分を持つモデルを用いる。パラメータの推定・検定には、 2 つの残差はそれぞれ一定の正規分布に従うものとして最尤推定す る REML 法 (残差最尤法または制限最尤法)を用いる注5)。

\section{2 会議内容による重回帰モデルの差異に関する考察}

分析には JMP10.0.2 ソフトウェアを用い、まず変量因子を用いな い通常の重回帰分析モデルにて変数増減法によるステップワイズ式 変数選択を行った後、変量因子を導入して REML 法により最終的な モデルを得た。その結果、「静かさ」の 1 次、2 次の項について主効 果および会議内容との交互作用項、「活気」について 1 次の項の主効 果のみ有意となった。このモデルにおける会議内容が[意思決定]の 場合の「静かさ」の要因効果がほぼ直線となった。そこで主効果と 交互作用として表現していた「静かさ」の要因効果を、会議内容の 水準ごとに効果が「枝分かれ」する要因として表現し直した上で、 モデルを構成する母数因子の推定值、検定結果などを Table7に示す。 なお、会議内容ごとの「活気」と「静かさ」の相関係数は意思決定 活動で-0.542、知識創造活動で-0.283 であり、VIF 值はいずれも 1.5 未満と小さく ${ }^{19)}$ 、多重共線性は回避されることを確認した注 6 。

Table7 より、「活気」の主効果と「静かさ[意思決定]」、「静かさ[知 識創造]」「静かさ $2[$ 知識創造]」の効果は全て有意である。ここで、 「静かさ」の 2 次の項に着目すると、意志決定活動においてはその 効果は有意ではなく、知識創造活動にの夕有意な効果を持つ $(p<0.05)$ 。この結果によれば、知識創造活動では「会話のしやすさ」 は「静かさ」の 2 次式で表現され、モデル推定に用いた形に忠実に 予測式のうち「静かさ」を含む項を書き下ろすと式 (1) のように表 される。

$$
y=-0.177 \cdot(x-3.375)^{2}+0.234 \cdot(x-3.375)+\cdots
$$

$x$ は「静かさ」の評価値、 $y$ は「会話のしやすさ」の評価值であり、 式（1）は以下の式（2）に変形できる。

$$
y=-0.177 \cdot(x-4.036)^{2}+\cdots
$$

式（2）より、知識創造活動において「会話のしやすさ」に対する 「静かさ」の要因効果は上に凸な曲線となっている。従って、「会話 
のしやすさ」が最大となる值をとる「静かさ」の評価值が存在し、 その值は $4.036 \fallingdotseq 4.0$ であることがわかる。つまり、「静かさ」の評価 が約 4.0 以上になると、「会話のしやすさ」の評価は下がる。前述の Fig. 4 より、「静かさ」の評価が 4.0 以上となる音環境条件は $40 \mathrm{~dB}$ 以下である。音環境条件と「会議のしやすさ」の関係を示した Fig.6 において、知識創造活動では $40 \mathrm{~dB}$ 以下で会議のしや寸さは有意に 低下しており、音環境が静か寸ぎると会話しやすさは低下し、その 結果として会議しやすさが低下寸ることが推察される。

知識創造活動の「会議のしやすさ」の重回帰モデルに式（2）を代 入すると、「会話のしやすさ」への効果を含めた「静かさ」の「会議 のしやすさ」への総合効果は式（3）のように表される。

$$
Y=0.614 \cdot\left\{-0.177 \cdot(x-4.036)^{2}+\cdots\right\}-0.156 \cdot x+\cdots
$$

$x$ は「静かさ」の評価値、 $Y$ は「会議のしやすさ」の評価值であり、 式（3）は以下の式（4）に変形できる。

$$
Y=-0.108 \cdot(x-3.314)^{2}+\cdots
$$

式（4）をみると、知識創造活動において「会議のしやすさ」に対 する「会話のしやすさ」への効果を含めた「静かさ」の総合効果も 上に凸な曲線となる。この結果から、「会議のしや寸さ」が最大とな る值をとる「静かさ」の評価值は $3.314 \fallingdotseq 3.3$ であることがわかる。 つまり、「静かさ」の評価が約 3.3 以上になると、「会議のしやすさ」 の評価は下がる。音環境条件との関連性を考察すると、前述の Fig.4 より、「静かさ」の評価が 3.3 以上となる音環境条件は $45 \mathrm{~dB}$ 付近よ り低いレベルであることがうかがえ、Fig.6 において知識創造活動で は $45 \mathrm{~dB}$ 以下の条件では $50 \mathrm{~dB}$ と比較して「会議のしやすさ」は有 意に低下していることが確認できる。

以上より、「会話しやすい」環境を構築するにあたっては静かな印 象は重要であるが、意思決定活動では静かなほど会話がしやすいと 感じるのに対し、知識創造活動に取り組むような空間では非常に静 かな環境になると会話のしやすさは低下し、会議しにくいという印 象に繋がることが示唆される。知識創造活動に取り組む空間では、 適度な静かさが会話しやすい印象をもたらし、その結果として会議 がしや寸くなることがうかがえる。

また、このモデルでは「活気」の主効果も有意であることから、 「活気」と音環境条件の関係を Fig.8 に整理した。会議内容ごとに 音環境条件を要因とした一元配置分散分析を行った結果、いずれの 会議内容でも音環境の主効果が有意に示され $(p<0.01)$ 、室内の騷音 レベルが低くなるほど「活気」の評価值は低下寸る傾向がみられた。 多重比較の結果を Fig.8 に示寸が、意思決定活動では暗騒音と $50 \mathrm{~dB}$ 、 $60 \mathrm{~dB}$ の各条件 $(p<0.01) 、 40 \mathrm{~dB}$ < $50 \mathrm{~dB} 、 60 \mathrm{~dB}$ の各条件 $(p<0.01) 、$ $45 \mathrm{~dB}$ と $60 \mathrm{~dB}$ の条件 $(p<0.05)$ で有意な差異が認められた。知識創 造活動では暗騒音と $50 \mathrm{~dB} 、 60 \mathrm{~dB}$ の各条件 $(p<0.01) 、 40 \mathrm{~dB}$ と $50 \mathrm{~dB}$ の条件 $(p<0.05)$ で差異が有意であった。この結果から、いずれの 会議内容でも室内の騒音レベルが $50 \mathrm{~dB}$ 以下で活気の評価值は有意 に低下寸るものの、活気を感じるようになるためには $45 \mathrm{~dB}$ 以上あ ればよいことが示唆される。

「会話のしやすさ」の重回帰モデルを会議内容ごとに整理すれば、 意思決定活動では「活気」「静かさ」の 1 次の項の主効果が有意と なっており、「活気」の評価が高いほど、あるいは「静かさ」の評価

\begin{tabular}{|c|c|c|c|}
\hline $\begin{array}{l}\text { Objective } \\
\text { variable }\end{array}$ & $\begin{array}{l}\text { Adjusted } \\
\text { R-square }\end{array}$ & Explanatory variable & $\begin{array}{c}\text { Partial regression } \\
\text { coefficient }\end{array}$ \\
\hline \multirow{6}{*}{$\begin{array}{l}\text { 会話の } \\
\text { しやすさ }\end{array}$} & \multirow{6}{*}{0.343} & 活気 & $0.310^{* *}$ \\
\hline & & 会議内容[意思決定] : 静かさ & $0.306^{* *}$ \\
\hline & & 会議内容[知識創造]: 静かさ & $0.234^{*}$ \\
\hline & & 会議内容[意思決定]：静かさ`2 & 0.033 \\
\hline & & 会議内容[知識創造]：静かさ^2 & $-0.177^{*}$ \\
\hline & & 会議内容 & -0.012 \\
\hline
\end{tabular}

Table7 Result of multiple regression analysis for "Ease of conversation"

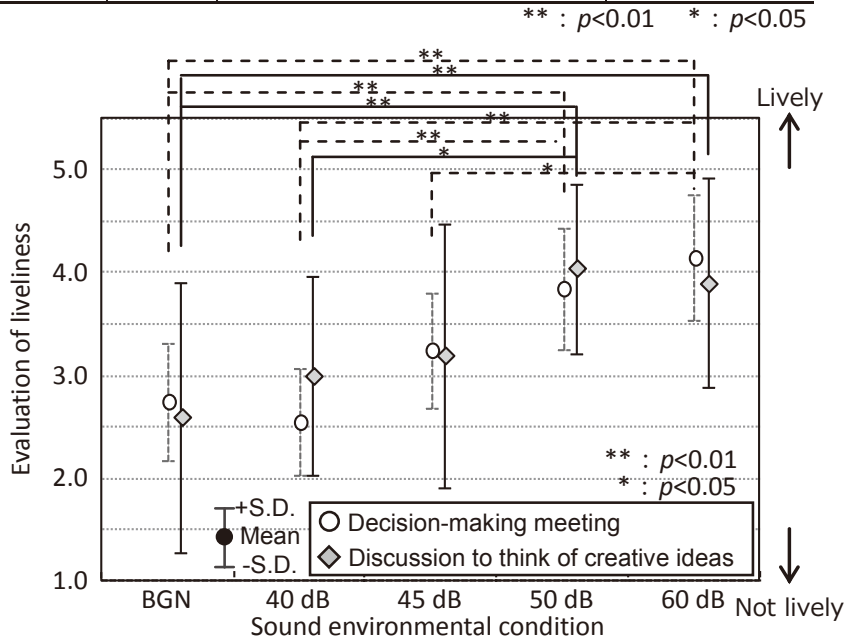

Fig.8 "Evaluation of liveliness" for each noise level

が高いほど、「会話しやすい」評価に繋がる。従って、室内の騒音レ ベルが低くなると「静かさ」の評価は上昇するが「活気」は低下し、 また、騒音レベルが高くなると「活気」の評価は上昇するが「静か さ」の評価は低下寸るので、意思決定活動では両効果が相殺された 結果、「会議のしやすさ」への音環境の影響は有意に表れなかった可 能性がある。

これに対し、知識創造活動では、「活気」、「静かさ」の 1 次の項と、 「静かさ」の 2 次の項の主効果が有意となっていることから、「会話 のしやすさ」に対して「静かさ」の要因効果が最大となる「静かさ」 の評価值が存在している。これについて、会話雑音のレベルと「静 かさ」や「活気」のそれぞれの評価值との関係を考察すると、Fig.4 より、会議内容に関わらず音環境条件が $45 \mathrm{~dB}$ 以下では静かな印象 が生じている。「活気」については、Fig.8 より、いずれの会議内容 でも室内の騒音レベルが $45 \mathrm{~dB}$ 以上あれば活気を感じやすいことが わかる。従って、静かな印象を損なわない $50 \mathrm{~dB}$ 未満で、活気を感 じやすい $45 \mathrm{~dB}$ 以上の音環境が「会話のしや寸さ」の評価が高くな り、「会議しやすい」という印象に繋がることが示唆される。

米国 GSA（General Services Administration）の設計ガイドライン ${ }^{21)}$ でも、「静かすぎる空間の不快感の改善対策」としてサウンドマスキ ングシステムの利用が位置付けられている。また、平栗ら 22),23) は、 大学の学生食堂という多群会話空間での会話しや寸さと音声明瞭度 や残響時間との関係を調べることを目的に、音環境の実測及びアン ケート調查を実施している。その成果として、利用者は自身の群に 属さない他の滞在者の音声が明瞭に聞こえるほど会話しにくいと感 じ、多群で会話する空間では必ずしも音声明瞭度が高いことが望ま しいとはいえないことが報告されている。これらの既往研究と本研 究の知見より、複数人で知識創造活動を行う会議では「静か寸ぎな い」環境が効率的な議論に繋がる可能性を示している。 


\section{5. むすび}

本研究では、対面会議によって複数人で知識創造活動を行う状況 を想定し、オフィス内で想定される騒音の一つとして、会話の内容 は理解できない複数の音声による会話雑音を環境音として用い、会 話雑音が「会議のしやすさ」に及ぼす影響を調べた。その成果とし て、本研究で得られた知見を以下に整理する。

(1)「会議のしやすさ」に寄与する「会話のしやすさ」の影響が最も 強く、会議内容に関わらず「会話をしやすくする」ことが「会議 のしやすさ」に繋がる。

(2)「聴き取りやすさ」はいずれの会議内容でも「会議のしやすさ」 に同程度の正の影響を持つという点は共通しているが、その影響 は「会話のしやすさ」よりも小さい。

(3) 知識創造活動では「会話のしやすさ」は「静かさ」の2 次式のモ デルで表され、「会話のしやすさ」に対する「静かさ」の 2 次の項 の係数は負で、上に凸の最適值が存在する関数形となる。

(4) 知識創造活動では、「静かさ」の「会話のしやすさ」への影響を 含めた「会議のしやすさ」に対する総合効果も 2 次式のモデルで 表され、「静かさ」の評価が高くなりすぎると、「会話のしやすさ」 が低下し、「会議のしやすさ」の評価は低下寸る。

(5) 知識創造活動では必ずしも静かな環境が望ましいとはいえず、本 実験の結果では、室内の騷音レベルは静かな印象が損なわれない ように $50 \mathrm{~dB}$ より低く、且つ活気が感じられやすい $45 \mathrm{~dB}$ 以上の 音環境が「会話のしやすさ」の評価は高くなり、「会議しやすい」 という印象に繋がることが示唆された。

\section{謝 辞}

本研究の協力者として、東京電機大学修士論文生 小熊淳 氏 $(\mathrm{H} 24$ 年度) に謝意を表する。本研究の成果の一部は H23 年度生産性研究 助成（研究代表者 : 辻村壮平）よるものである。

\section{参考文献}

1) 山本修一郎：知識創造デザイン技術の展開，NTT 技術ジャーナル，Vol.20, No.5, pp.8-11, 2008.5

2) 建築環境・省エネルギー機構, IBEC, 164, 特集 知的生産性, 2008.1

3) 小島隆矢, 伊丹弘美：人材の確保・活用におけるオフィス環境の寄与に関 する研究ーその 2 職務ストレス・モチベーションに着目した知的生産性モ デルー, 日本建築学会大会学術講演梗概集, 環境工学 1, pp.125-126, 2013.8.

4) 橋本頼幸, 新居洋子, 成瀬哲生 : 交通騒音の生理、作業能率、心理に及ぼ 寸影響に関する研究，日本建築学会計画系論文集, No.515, pp.25-31, 1999.1

5) 佐伯哲郎, 藤井健生, 山口静馬, 加藤裕一: 短期記憶作業時における騒音の 影響一うるささの心理的印象と作業成績一, 日本音響学会誌, Vol.59, No.4, pp.209-214,2003.4.

6) 辻村壮平，山田由紀子：脳波を用いた精神作業時の音の妨害感に関する基 礎的研究, 日本建築学会環境系論文集, No.608, pp.67-74, 2006.10

7) 羽田正沖, 西原直枝, 田辺新一：道路交通騒音が知的生産性に与える影響 に関する被験者実験，日本建築学会環境系論文集，Vol.73，No.625, pp.355-362, 2008.3.

8) 小熊淳, 古賀誉章, 佐野奈緒子, 辻村壮平, 秋田剛 : 暗記学習効率に音環境 が与える影響に関する研究，日本建築学会大会学術講演梗概集，環境工学 1 , pp.127-128, 2011.8

9) 佐久間哲哉, 上猶優美 : 執務空間の音環境が知的生産性に及ぼす影響につ いて, 日本音響学会建築音響研究会資料, AA2009-38, 2009.5.

10) 辻村壮平, 上野佳奈子 : 教室内音環境が学習効率に及ぼす影響, 日本建築 学会環境系論文集, Vol.75, No.653, pp.561-568, 2010.7.

11) 三上雄一郎, 佐久間哲哉: 初対面時における室内音環境と会話コミュニケ
ーションとの関係性についてーBGM の効果に関する実験的検討一, 日本建 築学会大会学術講演梗概集, 環境工学 1, pp.349-350, 2010.9.

12) 前田薫子, 金元圭, 吳冰琰, 松田雄二, 鯨井康志, 西出和彦: 室空間とレイ アウトが創造活動と心理評価に及ぼす影響に関する考察一オフィスにおけ る知的創造空間に関する実験的研究一, 日本建築学会計画系論文集, Vol.75, No.652, pp.1389-1398, 2010.6.

13) 2010２011 年版 AR/TV・Web 会議システム市場ービジュアル・コミュニ ケーション調査 Vol.2-, 矢野経済研究所, 2010.9.

14) 高木晴夫 : グループ意思決定会議のコミュニケーション構造一自己組織 性の観点からの観察研究, 電気学会論文誌 $\mathrm{C}$ 電子・情報・システム部門誌, Vol.114, No.3, pp.353-360, 1994.3.

15) 横山栄, 橘秀樹 : 公共空間における音環境の評価, 騒音制御, Vol.30, No.6, pp.477-481, 2006.12.

16) George Box : Use and Abuse of Regression, Technometrics, Vol.8, No.4, pp.625-629, 1966.11 .

17) 小島隆矢 : Excel で学ぶ共分散構造分析とグラフィカルモデリング，オー 么社, 2003.12.

18) 宮川雅巳：統計的因果推論一回帰分析の新しい枠組み一, 朝倉書店, 2004.4 .

19) 廣野元久, 林俊克: JMP による多変量データ活用術, 海文堂出版, 2008.9.

20) 日本建築学会編：住まいと街をつくるための調査のデザイン，オーム社, pp.156-163, 2012.3.

21) GSA Public Buildings Service : Sound Matters, pp.1-42, 2012.1.

22) 平栗靖浩, 上田麻理, 下山晃司, 川井敬二, 矢野隆 : 多群会話空間での会 話しやすさに関する検討一その 1 熊本大学工学部食堂における音環境計測 一, 日本音響学会春季研究発表会講演論文集, pp.1163-1164, 2013.3.

23) 平栗靖浩, 上田麻理, 川井敬二, 矢野隆 : 多群会話空間での会話しや寸さ に関する検討一その 2 会話しやすさと残響時間、RASTI の関係一, 日本建 築学会大会学術講演梗概集, 環境工学 $1, p p .185-186,2013.8$.

注

注 1) 被験者が作業する机の両脇にスピーカを設置することよる視覚的及び 聴覚的な違和感等の影響に関しては、本実験実施前に予備実験を行い、そ れらに対する違和感は特に生じていないことを予備実験の被験者の内省報 告によって確認した。

注 2) 分析途中の段階においては 2 次の項を無視しているため、残差不均一 となる場合があることを含意として注意深く分析を進めていく必要がある が、平均值まわりで中心化した形で 2 次の項を用いれば、 1 次の項との相関 は通常のコンディションの下では 0 に近くなり、点推定值としては大きな 偏りが生じない。従って、データの変動の範囲における全体的傾向をつか むためには十分に実用的で合理性がある方法である。

注 3) 説明変数間のVIF 值は「会話のしや寸さ」と「聴き取りやすさ」で意 思決定活動：1.38、知識創造活動：1.18、「会話のしやすさ」と「静かさ」 で意思決定活動 : 1.07 、知識創造活動 : 1.03 、「聴き取りや寸さ」と「静か さ」で意思決定活動 : 1.46、知識創造活動：1.32 でる。行列式は意思決定 活動で 0.496、知識創造活動では 0.641 であり、十分に大きい值をもってい るため、次元の縮約つまり多重共線性は発生していないことが明示的に示 される。

注 4)「静かさ」主効果と「静かさ×会議内容」交互作用をまとめて 1 つの 項として扱う（主効果付き交互作用として表す）ことになる。表現方法の 違いに過ぎないが、会議内容の水準ごとに要因効果を検定できるというメ リットがある。

注 5) REML 法による分析結果として、適切に推定された分母自由度による $\mathrm{F}$ 検定の結果も出力される。採用したモデルにおける「静かさ」1 次項の分 母自由度は 113.4、2 次の項の分母自由度は 183.6 と推定されている。1 次の 項については変量因子を導入せず $\mathrm{N}=200$ として分析した場合、かなりの「自 由度水増し」となることがわかる。なお、同様の議論は第 3 章の「会議し やすさ」を目的変数とした分析にもあてはまるが、この分析においても変 量因子を導入したモデル推定を行い、結果が大きく変わらないことを確認 している。

注 6)「活気」と「静かさ」の VIF 值は知識創造活動で 1.42、意思決定活動 で 1.09 である。 


\title{
INFLUENCE OF SOUND ENVIRONMENT IN MEETING ROOMS ON KNOWLEDGE CREATIVE
} ACTIVITY IN A GROUP

\author{
Sohei TSUJIMURA *1, Takeshi AKITA ${ }^{* 2}$, Takaya KOJIMA*3 \\ and Naoko SANO*4 \\ ${ }^{* 1}$ Assist. Senior Researcher, Architecture Laboratory, Railway Technical Research Inst. , Dr. Eng. \\ *2Prof., Dept. of Arch., Sch. of Sci. and Tech. for Future Life, Tokyo Denki Univ., Dr.Eng. \\ ${ }^{* 3}$ Assoc. Prof., Faculty of Human Sciences, WASEDA University, Dr.Eng. \\ ${ }^{*}$ Part-time Lect., Dept. of Arch., Sch. of Sci. and Tech. for Future Life, Tokyo Denki Univ., Dr.Eng.
}

Production values of industry offering products and services relevant to knowledge creating account for the most part of the Japanese economy. It has transformed from an industrial and physical economy to a knowledge economy. With the advent of knowledge creating society in recent years, construction of workplace environment to improve the productivity of intellectual activity is desired in office. In order to enhance workplace environment as knowledge creating space, active and smooth communication is required in the spaces to think up creative ideas such as meeting rooms and common areas in office.

In previous studies related to knowledge creative productivity and indoor sound environment, it was assumed that situations of conversation of two people, simple task and memorization to perform alone, knowledge creative activity such as writing essay. Thus, the most of previous studies related to them were investigated on task to be carried out in individual. In these studies, there were focused on the difference of level of knowledge activity or the activities in workspace with interpersonal perception. In a real-life office situation, knowledge creative activity was conducted in a group formed in more than one person. Therefore, it was necessary to find an effect of sound environment on it in a group. In this study, we focus on knowledge creative activity to carry out in a group, as a beginning, subjective experiments were conducted in order to find an influence of noise level in meeting room on "ease of meeting". This paper reports relationships between them during each meeting.

In our study, subjective experiments were conducted in the meeting room of the university. The groups of subject have each meeting during exposure to five kinds of sound environmental conditions. After each meeting under these sound environmental conditions, they were asked to evaluate the impression of sound environment, meeting space, the situation and outcome for meeting. Furthermore, to investigate psychological factors related to "ease of meeting", multiple regression analysis was performed.

From their results, in regard to "quietness of sound environment", we found that subjects start feeling noisy in sound environmental condition of noise level $50 \mathrm{~dB}$, and that of $60 \mathrm{~dB}$ have increased "listening difficulty of speech". Furthermore, in the condition of noise level $50 \mathrm{~dB}$, "ease of meeting" was the highest evaluation for discussion to think of creative ideas among experimental conditions. Also, sound environment of $50 \mathrm{~dB}$ produce lively discussion in group meetings such as discussion to think of creative ideas. We suggest that indoor sound environmental condition of ambient noise $50 \mathrm{~dB}$ was recommended to conduct it.

Furthermore, to investigate psychological factors related to "ease of meeting", multiple regression analysis was performed using the data obtained from subjective experiments. From the results of multiple regression analysis, we found that: (1) "ease of conversation" become the most important component of "ease of meeting" in both meetings; (2) "ease of meeting" is expressed in quadratic equation model of "quietness of sound environment"; (3) in discussion to think of creative ideas, if the evaluation of "quietness of sound environment" is too high, the evaluation of "ease of meeting" decreases because the evaluation of "ease of conversation" is reduced; (4) a quiet sound environment is not necessarily desirable in discussion to think of creative ideas. 
